\title{
CONSIDERATIONS ON THE ISSUES OF ADOPTION FROM THE PERSPECTIVE OF ECHR REGLEMENTATIONS
}

\author{
Cristian Sorin STĂNCIULESCU \\ "Lucian Blaga" University of Sibiu, Romania \\ stanciulescu.robert60@gmail.com
}

\begin{abstract}
The legal issue of adoption has an obvious complex character, a circumstance that involves increasing the effort of in-depth analysis of regulations in the field, both for their correct interpretation and application, and for identifying possible inaccuracies or legislative gaps and substantiating relevant legislative proposals for their elimination. Since the entry into force of the current Civil Code (2011) until now, in the Romanian doctrine, one cannot identify a scientific paper with a monographic character in which the theoretical and practical issues of the legal regime of adoption in the Romanian system of law are analyzed and deepened. The paper presents a series of opinions on possible corrections in the legal regime of adoption from the perspective ofECHR regulations.
\end{abstract}

\section{Keywords: legal, civil code, heritage, legislation, adoption}

\section{Introduction}

Taken over from ancient Roman law, in modern and contemporary times adoption has been traditionally established in some civil codes of civilized European states, such as: France (1804), Austria (1811), Italy (1865), Spain (1889), Germany (1900 ) and Switzerland (1907). Being reserved for adults in a first phase, adoption had as the main purpose the transmission of the patrimony and the name of the adopter without natural descendants to the adopted one. Later, especially starting with the $19^{\text {th }}$ century, the finality of adoption was substantially modified, putting in the foreground the emotional concerns, with the prevailing of the interest of children without parental care. In Europe, in the twentieth century, there was a real normative revolution in the field of adoption in terms of legislation. There is no other institution of family law that has suffered such a radical dynamic in terms of purpose, conditions of approval, procedure, effects, etc. Inserted in the state framework, the legal institution of adoption has gradually acquired international dimensions, mainly due to the recognition of the freedom of movement of individuals from one country to another and the universalization of civil rights.

Various reasons for this phenomenon [exceptional events (war, for example) or socio-economic misery in the country of origin] have led states to take consistent legislative measures to protect the interests of child protection. Throughout time, the social and legal issues of adoption have exceeded the competence of states. In addition to the unilateral measures taken by each state, international, multilateral or bilateral treaties were concluded, in which the principle of promoting and protecting the best interests of the child without parental protection prevailed. An impressive number of papers on various 
particular aspects of the legal regime of adoption have been elaborated and published in the Romanian doctrine [1]. Most of the approaches are found in family law papers, in which the analyses are usually synthetic and compliant. After the entry into force of the current Civil Code (October 1, 2011), the aspects of material law of adoption are regulated by this Code, and those of procedural law by Law no. 273/2004 and the new Code of Civil Procedure (2010).

According to some opinions, this new normative option is not considered to be properly reflected in recent doctrinal works, published after 2011. Going along the same idea, in these works in which various aspects of the legal regime of adoption are analyzed, the jurisprudence of the European Court of Human Rights and sometimes not even the domestic jurisprudence is usually capitalized. The analysis of the doctrine in the field reveals that, as a rule, the approaches are in accordance with the normative, doctrinal or jurisprudential solutions adopted, lacking the critical and contributory attitudes.

\section{Aspects of adoption in cases concerning private and family life, reflected in the ECHR jurisprudence}

In the context of the rapid transformations taking place in the social and legal issues, the need to study the influence of ECHR jurisprudence on the national law becomes absolutely necessary for a full understanding of the observance and development of the provisions of article 8 of the Convention, the one I chose to refer to in this paper. The European Convention on the Adoption of Children takes into account these social and legal developments, but at the same time respects the principles and provisions of the European Convention on Human Rights, always taking into account that the best interests of the child must take precedence over all other considerations. The methods by which we conducted this study are the identification, analysis and legal interpretation of some decisions of the Court, with possible effects in the field of national legislation on adoption.

The system of protection of fundamental rights and freedoms established by the European Convention on Human Rights ("the Convention") is based on the principle of subsidiarity. The importance of this principle was reaffirmed with the adoption of Protocol no. 15 of the Convention. The task of ensuring the application of the Convention rests primarily with the States parties to the Convention. The European Court of Human Rights ("the Court") intervenes only if the states have failed to fulfil their obligations. The activity of the Court is triggered mainly by individual applications, which may be submitted to the Court by any individual or nongovernmental legal person under the jurisdiction of a State party to the Convention. The pool of potential applicants is therefore vast: the entire population of the European Union, thirdcountry nationals living or in transit, associations, foundations, political parties, companies, etc. The vast majority of these individual applications are, however, rejected without being examined on the merits for failure to meet one of the admissibility criteria set out in the Convention. On 19 February 2010, representatives of the member states of the Council of Europe met in Switzerland to discuss the future of the Court and, in particular, the remaining cases in the large number of inadmissible applications. In a solemn declaration, they reaffirmed the Court's central role in the European system of protection of fundamental rights and freedoms and pledged to increase its effectiveness, while maintaining the principle of individual application. 


\subsection{ECHR regulations regarding adoption}

The first case studied concerns a claim against the Republic of Austria ( $\mathrm{X}$ and Others vs. Austria), which was brought before the Court under Article 34 of the Convention for the Protection of Human Rights and Fundamental Freedoms. The President of the Grand Chamber accepted the claimants' request that their identities not be disclosed. The three claimants are two women (claimants 1 and 3) in a stable relationship and the son of claimant 3 (claimant 2), who have lived in the same household since the child was 5 years old. In 2005, they signed an adoption agreement, by which the child was to be adopted by the first claimant (the female person who was in a relationship with his mother), being legally represented in this action by his mother, in order to create a legal relationship between the first claimant and the second, without interrupting the relationship with the child's mother.

According to the civil code of the Republic of Austria, the adoption of a child in a same-sex couple by the other partner could only be achieved by interrupting the relationship with the biological parent, the same not being valid in the case of heterosexual couples. The Constitutional Court was demanded to declare that provision to be discriminatory on the grounds of sexual orientation. In the ensuing steps, in order to change the articles of the Austrian Civil Code which prevented the the realisation of the adoption agreement, the applications were rejected both by the district and federal courts. The motivation for continuing the steps was based on the difference in treatment between the same-sex couples and different-sex couples. The Court unanimously declared the application admissible and ruled that there had been a violation of Article 14 of the Convention, in conjunction with Article 8, when the situation of the claimants is compared with that of an unmarried opposite-sex couple in which one partner wishes to adopt the child of the other partner.

In the case of $X$ and Others vs. Austria, the Court admits that there is discrimination related to family life, explaining that the approach was one that focused more on the interests of adults and not on the best interests of the child, the element which is at the heart of any adoption procedure, namely "providing a child with a family, not a family with a child" (see Fretté vs. France, No 36515/97, Art. 42, ECHR 2002I). With regard to the Frette vs. France case, which is chronologically prior to the above case, the circumstances of the case concern the possibility of a child being adopted by a single homosexual person. Although the French law allowed single women or men to adopt, he was denied the request to apply under an adopter program.

At the time, the Court ruled that the issues raised in this case should be dealt with separately by each State, both from the point of view of the legislator and the of other specialists involved in the adoption process, due to the lack of a common ground between Member States on the sensitive issues presented in this case. With regard to the adoption process, the Court reiterated a particularly important aspect, namely that the protection of the health and rights of children who may be involved in adoption are the primary elements to be taken into account in the legislation of any Member State.

Another case analyzed refers to a complaint made against France, which refused the request to adopt, on the grounds of lifestyle, namely that the complaint represented persons of the same sex [3]. Given that the French law expressly grants single persons the right to apply for an adoption authorization and also has an established procedure for this purpose, this request was granted because Article 14 of the Convention, in conjunction with Article 8, was therefore applicable in the present case. 
The Court's main observation with regard to the French administrative authorities and courts is that they based their decision to reject the application for authorization on two main grounds: the lack of a paternal reference in the applicant's household and the attitude of her partner. The reason for the lack of a paternal referent did not necessarily raise an issue per se, but, in the Court's view, such a reason, which risked to make ineffective the right of single persons to apply for authorization, could have led to an arbitrary refusal and they served as a pretext for rejecting the applicant's application on the grounds of homosexuality. [4]

The Court considered that the reference to the claimant's homosexuality was, if not explicit, at least implicit, and that the influence of the claimant's declared homosexuality on the assessment of her application was thus established as a decisive factor in the decision to refuse her authorization. Consequently, the domestic authorities made a distinction on the basis of considerations relating to his sexual orientation, an unacceptable distinction under the Convention. By analogy with the Frette case, a different approach can be seen from the Court's perspective, concluding that states may prohibit the adoption by unmarried persons, but their motivation must not be based on their sexual orientation. [5]

In this context, an approach from the perspective of international public law, with a view to capitalizing on the national jurisprudence and that of the European Court of Human Rights, will bring, in my opinion, a little light in improving the jurisprudential solutions.

\section{Conclusions}

As a result of the analysis performed on some ECHR decisions which have beenmade in the last three decades, it can be seen that the jurisprudence evolves with society, and the complexity of the legal phenomenon is closely related to the social one. With regard to the phenomenon of adoption, this remains one that is constantly changing and adapting to the changes in society. The most important actors involved in this process, the adoptee and the adopter, must be free from practices that favor arbitrariness, from interpretations of courts that do not place their fundamental rights and freedoms at the heart of the solutions, while maintaining the motivation of the best interests of the child.

On the other hand, an in-depth study of the jurisprudence of the European Court of Human Rights can make substantial contributions to the topic of the proposed doctoral scientific research, by capitalizing on decisions in the construction of various aspects of the legal regime of adoption, which involve delicate problems of society, such as redefining gender, relationships, and the involvement of medical progress in resetting the notion of family. The world is constantly changing, the notion of relationship is redefined, parenting becomes so diverse, and the responsibility of the legislator in the face of these challenges is to identify optimal solutions and properly assess all the aspects on which the development and well-being of adopted children depend.

\section{References List}

[1] Details of Treaty No.202 European Convention on the Adoption of Children (Revised), http://conventions.coe.int/

[2] ECHR, X and others vs. Austria, Appl. No.19010/07, Arrêt (Grand Chambre) 19/02/2013, http://hudoc.echr.coe.int/eng?i=001-116735

[3] ECHR, Case of Frette vs. France, Appl. No.36515/97, Former third section, 26/02/2002 
[4] ECHR, E.B.vs. France, Appl. no. 43546/02, Judgment (Grand Chamber) 22/01/2008 http://hudoc.echr.coe.int/fre?i=002-2311

[5] Dreptul familiei, IV ${ }^{\text {th }}$ edition, author T. Bodoașcă, revised and added by T. Drăghici and A. Murgu, published in Riso Print Publishing House, Cluj Napoca, 2020. 